ISTIGHNA, Vol. 2, No 2, Juli 2019 P-ISSN 1979-2824 E-ISSN 2655-8459

Homepage: http://e-journal.stit-islamic-village.ac.id/index.php/istighna

Ahmad Muzakkil Anam

Penanaman Nilai-Nilai Pendidikan Islam Multikultural di Perguruan Tinggi

Keagamaan Islam (Studi Kasus di Universitas Islam Malang)

\title{
PENANAMAN NILAI-NILAI PENDIDIKAN ISLAM MULTIKULTURAL DI PERGURUAN TINGGI KEAGAMAAN ISLAM (STUDI KASUS DI UNIVERSITAS ISLAM MALANG)
}

\author{
${ }^{1}$ Ahmad Muzakkil Anam \\ IAIN Surakarta \\ email: muzakkilzacky7@gmail.com
}

\begin{abstract}
Indonesia is a nation that has a very high level of diversity both in terms of ethnicity, race, ethnicity or religion. So it is not excessive if-then Indonesia is known as a multicultural nation. So, there needs to be an effort to inculcate the values of multicultural education at all levels of education that exist in Indonesia, including universities. This study used a qualitative approach with case study design. Data analysis techniques include data reduction, data presentation, and conclusion drawing. The results showed that: 1) the principles of planting the values of multicultural Islamic education at Unisma were based on several principles, namely: openness, tolerance (tolerance), unity in diversity, and Islam rahmatan lil 'alamin as leader; 2) the implementation of the planting of multicultural education values in Unisma is patterned into two, namely multicultural knowing and multicultural feeling. Multicultural knowing is given through several activities such as New Student Campus Life Orientation (Oshika Maba), Halaqoh Diniyah, and Islamic Religion 1-5. The multicultural feeling is instilled through student day activities; and 3) the cultivation of the values of multicultural education at Unisma has positive implications for the tolerance attitude of Unisma students.
\end{abstract}

Keywords: Education; Islam; Multicultural

\begin{abstract}
Abstrak: Indonesia adalah bangsa yang memiliki tingkat keberagaman yang sangat tinggi baik itu dalam hal suku, ras, etnis atau pun agama. Sehingga tidaklah berlebihan jika kemudian Indonesia dikenal sebagai bangsa yang multikultural. Sehingga, perlu adanya upaya untuk menanamkan nilai-nilai pendidikan multikultural di semua jenjang pendidikan yang ada di Indonesia, termasuk perguruan tinggi. Penelitian ini menggunakan pendekatan kualitatif dengan rancangan studi kasus. Teknik analisis data meliputi reduksi data, penyajian data, dan penarikan kesimpulan. Hasil penelitian menunjukkan, bahwa: 1) prinsipprinsip penanaman nilai-nilai pendidikan Islam multikultural di Unisma didasarkan pada beberapa prinsip, yaitu: keterbukaan (openness), toleransi (tolerance), bersatu dalam perbedaan (unity in diversity), dan Islam rahmatan lil'alamin sebagai leader; 2) implementasi penanaman nilai-nilai pendidikan multikultural di Unisma terpolakan menjadi dua, yaitu multicultural knowing dan multicultural feeling.Multicultural knowing diberikan melalui beberapa kegiatan seperti Orientasi Kehidupan Kampus Mahasiswa Baru (Oshika Maba), Halaqoh Diniyah, dan Mata Kuliah Agama Islam 1-5. Adapun multicultural feeling ditanamkan melalui kegiatan student day; dan 3) penanaman nilai-nilai pendidikan multikultural di Unisma memiliki implikasi yang positif terhadap sikap toleransi para mahasiswa Unisma.
\end{abstract}

\section{Kata Kunci: Pendidikan; Islam; Multikultural}

Peer reviewed under reponsibility of STIT ISLAMIC VILLAGE.

(C) 2018 STIT ISLAMIC VILLAGE, All right reserved, This is an open access article under

the CC BY SA license (https://creativecommons.org/licenses/by-sa/4.0/) 
ISTIGHNA, Vol. 2, No 2, Juli 2019 P-ISSN 1979-2824 E-ISSN 2655-8459

Homepage: http://e-journal.stit-islamic-village.ac.id/index.php/istighna

Ahmad Muzakkil Anam

Penanaman Nilai-Nilai Pendidikan Islam Multikultural Di Perguruan Tinggi

Keagamaan Islam (Studi Kasus Di Universitas Islam Malang)

\section{A. PENDAhuluan}

Bangsa Indonesia merupakan bangsa yang majemuk, karena memiliki akar keberagaman dalam hal agama, bahasa, tradisi dan budaya. Terkait dengan agama misalnya, setidaknya ada enam agama yang diakui secara resmi oleh pemerintah. ${ }^{1}$ Belum lagi dengan kepercayaan-kepercayaan lainnya yang juga tumbuh subur di Indonesia. Ini baru dalam konteks agama, belum lagi ketika berbicara tentang suku, ${ }^{2}$ etnik, ras serta budaya yang ada dalam masyarakat Indonesia yang menjadi ciri khas dan kekayaan dari bangsa Indonesia.

Meskipun demikian, beberapa dekade terakhir ini, keragaman yang ada di Indonesia mulai menampakkan sisi negatifnya, yaitu seringkalinya terjadi konflik di masyarakat yang berlandaskan atas perbedaan baik suku, etnis, ras maupun agama. Sebut saja kasus kasus Ambon dan Poso (konflik antar agama), Sambas dan Sampit (konflik antar etnis Dayak/Melayu dengan Madura), belum lagi kasus-kasus penyerangan terhadap Jamaah Ahmadiyah di berbagai tempat, kemudian tahun 2013 kasus penyerangan terhadat kaum Syi'ah di sampang Madura. Belum lagi ketika berbicara tentang kebebasan dalam beragama, banyak terjadi beberapa konflik di dalam susunan masyarakat yang heterogen secara agama yang masih marak terjadi setiap tahunnya. ${ }^{3}$ Melihat fakta tersebut, beberapa pihak kemudian mulai mempertanyakan peran pendidikan, khususnya pendidikan agama yang menurut PP No. 5/2007, Bab I, Pasal 1, diberikan pada setiap jenjang pendidikan dari yang paling dasar hingga perguruan tinggi.

1 Imron Rossidy, Pendidikan Berparadigma Inklusif Upaya Memadukan Pengokohan Akidah dengan Pengembangan Sikap Toleransi dan Kerukunan, (Malang: UIN Malang Press, 2009), hal. 1

2 Data terakhir yang dikeluarkan oleh Badan Pusat Statistik, suku bangsa yang ada di Indonesia lebih dari 1300 suku. Lihat Tim Penulis, Kewarganegaraan, Suku Bangsa, Agama, dan Bahasa Sehari-hari Penduduk Indonesia; Hasil Sensus Penduduk 2010, (Jakarta: Badan Pusat Statistik, 2011), hal. 5

${ }^{3}$ Pada tahun 2015 SETARA Institute mencatat 196 peristiwa pelanggaran kebebasan beragama/berkeyakinan dengan 236 bentuk tindakanyang tersebar di 26 provinsi. ${ }^{3}$ Lihat Halili dan Bonar Tigor Naipospos, Laporan Kondisi Kebebasan Beragama/Berkeyakinan di Indonesia 2015; Politik Harapan Minim Pembuktian, (Bendungan Hilir: Pustaka Masyarakat Setara, 2016), hal. 32. Sementara itu, The Wahid Institue memberikan laporan sementaranya terkait pelanggaran kebebasan beragama/berkeyakinan sepanjang tahun 2015 berjumlah 147 peristiwa. Lihat http://www.wahidinstitute.org/wi-id/, diakses tanggal 21 Januari 2016.

Kemudian, jika dibandingkan dengan tahun sebelumnya, dari data yang ada di Setara Institute menunjukkan adanya peningkatan pelanggaran kebebasan beragama/keyakinan, di mana pada tahun 2014 Setara Institue mencatat adanya tindak pelanggaran kebebasan dalam beragama sebanyak 134 peristiwa dengan 177 tindakan. Lihat Halili dan Bonar Tigor Naipospos, Dari Stagnasi Menjemput Harapan Baru: Kondisi Kebebasan Beragama/Berkeyakinan Di Indonesia Tahun 2014, (Bendungan Hilir: Pustaka Masyarakat Setara, 2015), hal. 30. Sedangkan pada tahun sebelumnya, The Wahid Institue melaporkan adanya 158 peristiwa dan 187 tindakan pelanggaran dalam kebebasan beragam dan berkeyakinan yang ada di Indonesia. Lihat Tim Penyusun, Laporan Tahunan Kebebasan Beragama / Berkeyakinan Dan Intoleransi 2014 The Wahid Institute, (Jakarta: The Wahid Institute, 2014), hal. 21. Melihat riwayat pelanggaran dalam kebebasan beragama/keyakinan yang masih fluktuatif ini menandakan bahwa ancaman dengan latar belakang keberbedaan, utamanya keberbedaan agama masih sangat tinggi dan bisa menjadi api dalam yang kapan saja api itu bisa berkobar semakin besar. 
ISTIGHNA, Vol. 2, No 2, Juli 2019 P-ISSN 1979-2824 E-ISSN 2655-8459

Homepage: http://e-journal.stit-islamic-village.ac.id/index.php/istighna

Ahmad Muzakkil Anam

Penanaman Nilai-Nilai Pendidikan Islam Multikultural Di Perguruan Tinggi

Keagamaan Islam (Studi Kasus Di Universitas Islam Malang)

Pendidikan agama saat ini dinilai gagal dalam mencetak generasi-generasi muda yang sadar akan realitas multikultural yang dimiliki bangsa ini. ${ }^{4}$ Sehingga, upaya untuk mereformulasi pendidikan agama yang memiliki landasan multikultural perlu dikembangkan dalam rangka menumbuhkan kesadaran multikultural bagi generasi-generasi muda penerus bangsa yang dikenal dengan keberagamannya ini.

Kaitannya dengan kegagalan pendidikan agama dalam mencetak pribadipribadi yang memiliki kesadaran multikultural ini menurut Kautsar Azhari Noer, seperti yang dikutip oleh Ali Maksum, ${ }^{5}$ disebabkan beberapa hal. Pertama, penekanannya pada proses transfer ilmu agama ketimbang pada proses transformasi nilai-nilai keagamaan dan moral kepada anak didik; kedua, sikap bahwa pendidikan agama tidak lebih dari sekedar sebagai "hiasan kurikulum" belaka, atau sebagai "pelengkap" yang dipandang sebelah mata; ketiga, kurangnya perhatian untuk mempelajari agama-agama lain; dan keempat, kurangnya penekanan pada penanaman nilai-nilai moral yang mendukung kerukunan antar agama, seperti cinta, kasih sayang, persahabatan, suka menolong, suka damai dan toleransi.

Dari beberapa sebab kegagalan pendidikan agamatersebut, beberapa lembaga pendidikan temasuk Perguruan Tinggi sudah mulai membenahi diri, salah satunya adalah Universitas Islam Malang (selanjutnya disebut Unisma). Unisma dalam hal ini menyadari akan pentingnya mengupayakan penanaman nilai-nilai pendidikan multikultural sebagai salah satu upaya meminimalisir konflik-konflik atas nama perbedaan yang marak terjadi akhir-akhir ini.

\section{B. LANDASAN TEORI}

\section{Penanaman Nilai}

Menurut Thomas Lickona, untuk menanamkan suatu nilai sehingga dapat menjadi karakter tertentu diperlukan beberapa tahapan. Ketiga komponen tersebut adalah sebagai berikut: ${ }^{6}$

a) Moral Knowing

Moral knowing (pengetahuan moral) berhubungan dengan bagaimana seorang individu mengetahui sesuatu nilai yang abstrak.

\footnotetext{
${ }^{4}$ Kautsar Azhari Noer, menyebutkan bahwa setidaknya terdapat empat faktor penyebab kegagalan pendidikan agama dalam menumbuhkan kesadaran multikultural. Pertama, penekanannya pada proses transfer ilmu agama ketimbang pada proses transformasi nilai-nilai keagamaan dan moral kepada anak didik; kedua, sikap bahwa pendidikan agama tidak lebih dari sekedar sebagai "hiasan kurikulum" belaka, atau sebagai "pelengkap" yang dipandang sebelah mata; ketiga, kurangnya penekanan pada penanaman nilai-nilai moral yang mendukung kerukunan antar agama, seperti cinta, kasih sayang, persahabatan, suka menolong, suka damai dan toleransi; dan keempat, kurangnya perhatian untuk mempelajari agama-agama lain. Lihat Ali Maksum, Pluralisme dan Multikulturalisme; Paradigma Baru Pendidikan Islam di Indonesia, (Malang: Aditya Media Publishing, 2011), hal. 204
}

${ }^{5}$ Ali Maksum, Pluralisme dan Multikulturalisme; Paradigma Baru Pendidikan Islam di Indonesia, (Malang: Aditya Media Publishing, 2011), hal. 204

${ }^{6}$ Thomas Lickona, Educating for Character How Our School Can Teach Respect and Responsbility, (New York: Bantam Bookss, 1992), hlm. 53-62 
ISTIGHNA, Vol. 2, No 2, Juli 2019 P-ISSN 1979-2824 E-ISSN 2655-8459

Homepage: http://e-journal.stit-islamic-village.ac.id/index.php/istighna

Ahmad Muzakkil Anam

Penanaman Nilai-Nilai Pendidikan Islam Multikultural Di Perguruan Tinggi

Keagamaan Islam (Studi Kasus Di Universitas Islam Malang)

Dengan kata lain, komponen pertama ini lebih mengedepankan aspek kognitif.

b) Moral Feeling

Moral feeling (perasaan moral). Moral feeling (sikap moral) merupakan tahapan tingkat lanjut, dimana jika pada komponen pertama penekanannya lebih pada aspek pengetahuan/kognitif, maka pada komponen kedua ini lebih ditekankan pada aspek perasaan/afektif, dimana peserta didik dapat merasakan dan mempercayai akan apa yang telah mereka terima pada komponen pertama.

c) Moral Action

Setelah peserta didik berada pada komponen kedua, selanjutnya moral feeling yang telah dimiliki diarahkan untuk dapat masuk pada komponen ketiga, yaitu moral action (perilaku moral).

Agar penanaman nilai dapat berhasil, maka ketiga komponen di atas harus saling terkait satu sama lain. Hubungan antar ketiga komponen di atas dapat diilustrasikan sebagai berikut:

Gambar 1. Hubungan antara Moral Knowing, Moral Feeling, dan Moral Action (Sumber: Thomas Lickona, 1992)

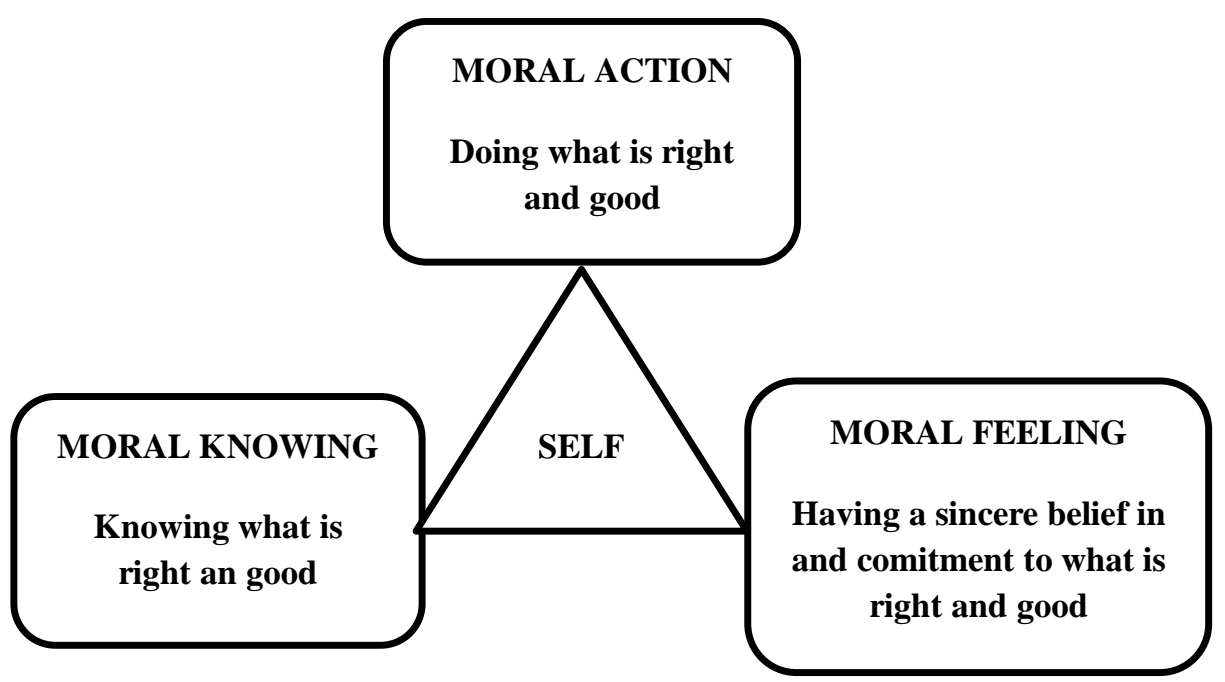

Garis yang menghubungkan antara satu dimensi dengan dimensi lainnya menunjukkan bahwa untuk membangun karakter termasuk di dalamnya adalah internalisasi nilai, diperlukan pengembangan ketiga-tiganya secara terpadu. Dengan kata lain, penumbuhan karakter ini tidak cukup hanya dengan memiliki pengetahuan tentang yang baik saja, melainkan juga dapat merasakan dan mengerjakannya. Sehingga, pada tataran moral action misalnya, agar peserta didik terbiasa (habit) memiliki kemauan (will) dan kompeten (competence) dalam menginternalisasikan nilai-nilai pendidikan multikultural, diperlukan penciptaan suasana multikultural di lingkungan setempat dan itu pun menuntut adanya intensitas dan berulang-ulang. Jika tidak, maka yang terjadi justru sebaliknya. Hal ini disebabkan karena nilai- 
ISTIGHNA, Vol. 2, No 2, Juli 2019 P-ISSN 1979-2824 E-ISSN 2655-8459

Homepage: http://e-journal.stit-islamic-village.ac.id/index.php/istighna

Ahmad Muzakkil Anam

Penanaman Nilai-Nilai Pendidikan Islam Multikultural Di Perguruan Tinggi

Keagamaan Islam (Studi Kasus Di Universitas Islam Malang)

nilai yang berorientasi inklusif kadang-kadang terkalahkan oleh nilai-nilai sebelumnya yang tertanam lebih dulu yang itu bernuansa inklusif. ${ }^{7}$

\section{Nilai-nilai Pendidikan Multikultural}

UNESCO pada bulan Oktober 1994 di Jenewa telah merekomendasikan bahwa dalam pendidikan multikultural setidaknya harus memuat beberapa pesan, bahwa dalam pendidikan multikultural memuat nilai-nilai sebagai berikut:

a. Nilai Toleransi

Toleransi merupakan kemampuan untuk dapat menghormati sifatsifat dasar, keyakinan, dan perilaku yang dimiliki orang lain. Selain itu, toleransi juga bisa dipahami sebagai sifat atau sikap menghargai, membiarkan atau membolehkan pendirian (pandangan, pendapat, kepercayaan kebiasaan, kelakuan dan sebagainya) orang lain yang bertentangan dengan kita. Atau dengan kata lain, hakikat toleransi adalah hidup berdampingan secara damai (peaceful coexistence) dan saling menghargai di antara keragaman (mutual respect). ${ }^{8}$

b. Nilai Demokrasi/kebebasan

Nilai demokrasi ini mengandung pengertian adanya pandangan hidup yang mengutarakan persamaan hak dan kewajiban serta perlakuan yang sama di dalam berlangsungnya proses belajar-mengajar antara pendidik dan pserta didik, serta keterlibatan lembaga pendidikan.

c. Nilai Kesamaan/kesetaraan

Dalam pendidikan, nilai kesamaan ini adalah adanya proses pendidikan yang tidak menjadikan dan memperlakukan peserta didik satu lebih spesial dari peserta didik lainnya, atau sebaliknya menjadikan salah satu peserta didik lebih rendah dari peserta didik lainnya dengan alasan apa pun. Apakah itu terkait dengan fasilitas yang diberikan atau pun perlakuan dari pendidik atau lembaga pendidikan itu sendiri.

d. Nilai Keadilan

Dalam hal ini, keadilan dapat diartikan sebagai membagi sama banyak, atau memberikan hak yang sama kepada orang-orang atau kelompok dengan status yang sama. Misalnya, semua peserta didik dengan kompetensi yang sama berhak mendapatkan nilai yang sama dalam mata pelajaran yang sama.

Selain itu, keadilan juga bisa diartikan dengan memberikan hak yang seimbang dengan kewajiban, atau memberi seseorang sesuai dengan porsi kebutuhannya. Sebagai contoh, dalam pendidikan, orang tua bisa dikatakan adil jika dalam pembiayaan pendidikan anak-anaknya sesuai dengan tingkat kebutuhan masing-masing, meskipun secara nominal masing-masing anak tidak sama jumlahnya.

${ }^{7}$ Sulalah, Pendidikan Multikultural Didaktika Nilai-nilai Universalitas Kebangsaan, (Malang, UIN-Maliki Press, 2011),hlm. 107

${ }^{8}$ Moh. Yamin dan Vivi Aulia, Meretas Pendidikan Toleransi; Pluralisme dan Multikulturalisme Sebuah Keniscayaan Peradaban, (Malang: Madani Media, 2011), hlm. 6 
ISTIGHNA, Vol. 2, No 2, Juli 2019 P-ISSN 1979-2824 E-ISSN 2655-8459

Homepage: http://e-journal.stit-islamic-village.ac.id/index.php/istighna

Ahmad Muzakkil Anam

Penanaman Nilai-Nilai Pendidikan Islam Multikultural Di Perguruan Tinggi

Keagamaan Islam (Studi Kasus Di Universitas Islam Malang)

Untuk masing-masing nilai terdapat beberapa indikator. Tabel berikut akan dipaparkan indikator dari setiap nilai-nilai multikultural dalam pendidikan:

Tabel 2. Indikator Nilai-nilai Pendidikan Multikultural

\begin{tabular}{|c|l|l|}
\hline No & \multicolumn{1}{|c|}{$\begin{array}{c}\text { Nilai-nilai } \\
\text { Pendidikan } \\
\text { Multikultural }\end{array}$} & \multicolumn{1}{c|}{ Indikator } \\
\hline 1 & Nilai Toleransi & $\begin{array}{l}\text { Sikap menghargai, membiarkan, atau } \\
\text { membolehkan pendirian (pandangan, } \\
\text { pendapat, kepercayaan, kebiasaan, } \\
\text { kelakuan, dan sebagainya). }\end{array}$ \\
\hline 2 & Nilai Demokrasi & $\begin{array}{l}\text { Kebebasan dalam memilih profesi, } \\
\text { memilih hobi atau minat, memilih } \\
\text { wilayah hidup, bahkan dalam } \\
\text { menentukan pilihan agama pun tidak } \\
\text { dapat dipaksa. }\end{array}$ \\
\hline 3 & Nilai kesetaraan & $\begin{array}{l}\text { Sama tingkatan (kedudukan, pangkat), } \\
\text { menunjukkan adanya tingkatan yang } \\
\text { sama, kedudukan yang sama, tidak } \\
\text { lebih tinggi atau lebih rendah antara } \\
\text { satu sama lain. }\end{array}$ \\
\hline 4 & Nilai Keadilan & $\begin{array}{l}\text { Keseimbangan atau keharmoniasan } \\
\text { antara menuntut hak dan menjalankan } \\
\text { kewajiban. }\end{array}$ \\
\hline
\end{tabular}

\section{METODE PENELITIAN}

Dalam penelitian ini digunakan pendekatan kualitatif deskriptif, yaitu prosedur penelitian yang menghasilkan data deskriptif berupa kata-kata tertulis atau lisan dari orang-orang dan perilaku yang dapat diamati, dengan sumber datanya yang terdiri dari data primer dan data sekunder. Untuk data primer adalah data yang diperoleh dari hasil wawancara dengan Dewan Pembina Yayasan Universitas Islam Malang, Pimpinan Universitas Islam Malang, beberapa dosen dan Mahasiswa di Universitas Islam Malang. Sedangkan data sekunder diperoleh dari dokumentasi baik berupa teks, soft-file, maupun dokumen lain yang terkait dengan fokus penelitian di Universitas Islam Malang.

Setelah data tersebut terkumpul, langkah selanjutnya adalah menganalasisnya. Langkah peneliti dalam menganalisis data tersebut dimulai dengan menelaah seluruh data yang telah terkumpul. Data tersebut tentunya sangat banyak, setelah dibaca dan dipelajari, maka langkah berikutnya adalah melibatkan tiga komponen analisis, yaitu: (1) reduksi data (data reduction), (2) penyajian data (data display), dan (3) penarikan kesimpulan (verification). Ketiga komponen analisis tersebut bersifat interaktif.

Sementara itu, dalam rangka menjaga keabsahan data dalam penelitian ini, penulis menggunakan tiga kriteria keabsahan data, yaitu kredibilitas atau derajat kepercayaan, dependabilitas atau kebergantungan, dan konfirmabilitas atau kepastian. 
ISTIGHNA, Vol. 2, No 2, Juli 2019 P-ISSN 1979-2824 E-ISSN 2655-8459

Homepage: http://e-journal.stit-islamic-village.ac.id/index.php/istighna

Ahmad Muzakkil Anam

Penanaman Nilai-Nilai Pendidikan Islam Multikultural Di Perguruan Tinggi

Keagamaan Islam (Studi Kasus Di Universitas Islam Malang)

\section{HASIL PENELITIAN}

1. Prinsip-prinsip Penanaman Nilai-nilai Pendidikan Islam Multikultural di Universitas Islam Malang

Unisma adalah salah satu universitas yang dikenal sebagai kampus multikultural. Sebutan sebagai kampus multikultural ini tentu bukan tanpa sebab. Karena memang pada kenyataannya Unisma memiliki mahasiswa yang berasal dari hampir semua provinsi yang ada di Indonesia. ${ }^{9}$

Keberagaman yang ada di Unisma pun tidak berhenti pada daerah asal mahasiswanya, melainkan juga pada agama yang dipeluk oleh mahasiswa Unisma. Meskipun Unisma mengusung identitas keislaman, namun pada kenyataannya Unisma juga menerima mahasiswa non-Islam juga. Data terakhir menyebutkan bahwa di Unisma terdapat 13 mahasiswa yang beragama non-Islam. Diantaranya agama Katholik 10, Budha 2, dan 1 mahasiswa beragama Hindu.

Menyikapi akan keberagamannya ini, kemudian Unisma mengupayakan untuk menanamankan nilai-nilai pendidikan multikultural bagi para mahasiswa. Dengan demikian, diharapkan mahasiswa Unisma bisa menyikapi keberagaman yang ada di sekitarnya baik itu dalam lingkup universitas atau kebangsaan dengan sikap yang positif.

Setelah penulis menggali informasi dari beberapa informan kunci, disertai dengan beberapa data pendukung. Diperoleh gambaran bahwa dalam menanamkan nilai-nilai pendidikan multikultural ini, Unisma mendasarkan pada beberapa prinsip, diantaranya:

\section{a. Keterbukaan (openness).}

Yaitu sikap terbuka untuk menerima siapa saja yang ingin belajar di Unisma yang telah dibuktikan dengan Unisma tidak membatasi hanya menerima mahasiswa yang Islam saja atau yang hanya berasal dari daerah tertentu. Melainkan menerima mahasiswa dengan latar belakang yang beraneka warna. Tidak itu saja, Unisma juga membuka diri untuk memperoleh pelajaran dari pihak manapun dalam bentuk kerjasama-

\footnotetext{
${ }^{9}$ Data terakhir yang dimiliki Unisma mencatat bahwa mahasiswa dengan daerah asal Jawa Timur sejumlah 5919 (96,78\%); kemudian Jawa Tengah, 115 (1,88\%); Jawa Barat, 50 (0,82\%); DKI Jakarta, 18 (0,29\%); dan Banten, 14 (0,23\%). Dilanjutkan mahasiswa yang berasal dari luar Jawa. Unisma mencatat mahasiswa dari NTT sejumlah 187, dan NTB 336. Kemudian disusul dengan Kalimantan dengan presentase 88 mahasiswa dari Kalimantan Barat; 62 mahasiswa dari Kalimantan Tengah; 73 mahasiswadari Kalimantan Selatan; 116 mahasiswa dari Kalimantan Timur; dan 13 mahasiswa dari Kalimantan Utara. Setalah itu disusul dengan daerah Sumatera dengan presentase 24 mahasiswa dari Nangroe Aceh darussalam; 17 mahasiswa dari Sumatera Utara; 5 mahasiswa dari Sumatera Barat; 30 mahasiswa dari Riau; 23 mahasiswa dari Kepulauan Riau; 21 mahasiswa dari Jambi; 33 mahasiswa dari Sumatera Selatan; 7 mahasiswa dari Bangka Belitung; 5 mahasiswa dari Bengkulu; dan 47 mahasiswa dari Lampung. Dilanjutkan dengan daerah Maluku yang terdiri dari Maluku dengan jumlah mahasiswa 88 dan Maluku Utara 29 mahasiswa. Kemudian Sulawesi, dengan presentase 3 mahasiswa dari Sulawesi Utara; 5 mahasiswa dari Sulawesi Barat; 17 mahasiswa dari Sulawesi Tengah; 21 mahasiswa dari Sulawesi Tenggara; dan 2 mahasiswa dari Gorontalo. Kemudian Bali dengan jumlah mahasiswa 43. Terakhir adalah daerah Papua dengan jumlah 14 mahasiswa dari Papua Barat dan dan 22 Papua sendiri. Diolah dari Biro Administrasi Umum dan Keuangan Unisma.
} 
Penanaman Nilai-Nilai Pendidikan Islam Multikultural Di Perguruan Tinggi Keagamaan Islam (Studi Kasus Di Universitas Islam Malang)

kerjasama baik kerjasama dalam atau luar negeri. Dalam kerjasama ini, Unisma tidak membatasi hanya berkenan bekerjasama dengan pihak Islam saja, tapi juga sangat membuka diri untuk bekerjasama dengan pihak-pihak yang notabene-nya tidak memiliki identitas keislaman layaknya Unisma. Bahkan, menurut Ketua Dewan Pengasuh Yayasan Unisma, Prof. DR. K.H. Tholchah Hasan, dan didukung dari data yang dimiliki oleh Kantor Urusan Internasional (KUI) Unismaa, nampak bahwa Unisma lebih banyak bekerjasama dengan universitasuniversitas non-Islam dibanding dengan yang Islam.

b. Toleransi (tolerance).

Salah satu dampak dari keterbukaan yang menjadi prinsip pertama dalam pengembangan pendidikan Islam berbasis multikultural adalah menjadikan Unisma dihuni oleh mahasiswa dari berbagai latar belakang yang berbeda. Keberbedaan ini jika tidak disikapi dengan bijaksana, maka akan berpotensi menimbulkan konflik antar mahasiswa. Karenanya, prinsip selanjutnya yang diusung adalah toleransi. Toleransi di sini dimaknai sebagai sikap saling menghargai, saling menghormati, dan tidak semen-mena terhadap pihak yang tidak dominan. Artinya, bukan karena suatu kelompok nampak lebih dominan dibanding kelompok lain, menjadikan kelompok dominan ini bisa dengan semenmena dan memaksakan untuk menerapkan nilai-nilai yang diyakininya terhadap kelompok lain yang tidak menutup kemungkinan memiliki nilai-nilai yang berbeda.

c. Bersatu dalam Perbedaan (Unity in Diversity).

Sebagai lanjutan dari prinsip sebelumnya, bahwa tidak ada tindakan semena-mena yang boleh dilakukan oleh kelompok yang mayoritas terhadap kelompok yang minoritas. Melainkan setiap kelompok yang ada tersebuttetap diberikan kesempatan yang sama untuk mempertahankan ciri khas yang dimilikinya. Sehingga prinsip kebersatuan (unity) diikuti dengan "dalam perbedaan" (in diversity), karena memang Unisma menghendaki mahasiswa Unisma bisa bersatu dengan tanpa menghilangkan ciri khas yang dibawa oleh tiap-tiap mahasiswa Itulah mengapa, Unisma tetap memberikan kesempatan serta memfasilitasi para mahasiswa untuk mengekspresikan apa yang menjadi ciri khas dari kebudayaan yang dimilikinya.

\section{d. Islam Rahmatan Lil'alamin sebagai Leader.}

Prinsip Islam rahmatan lil'alamin sebagai leader ini dimaksudkan agar setiap tindakan senantiasa didasari akan nilai-nilai Islam yang memang dapat memberikan manfaat tidak hanya kepada orang Islam saja, melainkan kepada semua manusia, bahkan kepada sekalian alam.

\section{Implementasi Penanaman Nilai-nilai Pendidikan Multikultural di Universitas Islam Malang}

Terkait dengan implementasi penanaman nilai-nilai pendidikan multikultural ini, Unisma memiliki beberapa kegiatan, yang secara garis 
ISTIGHNA, Vol. 2, No 2, Juli 2019 P-ISSN 1979-2824 E-ISSN 2655-8459

Homepage: http://e-journal.stit-islamic-village.ac.id/index.php/istighna

Ahmad Muzakkil Anam

Penanaman Nilai-Nilai Pendidikan Islam Multikultural Di Perguruan Tinggi

Keagamaan Islam (Studi Kasus Di Universitas Islam Malang)

besar kegiatan tersebut terpolakan menjadi dua, yaitu kegiatan yang terkait dengan multicultural knowing dan multicultural feeling.

\section{a. Multicultural knowing}

Dimaksudkan untuk memberikan wawasan atau pengetahuan terkait dengan multikultural. Hal ini amatlah penting, mengingat tidak semua mahasiswa baru yang ada di Unisma memiliki pengetahuan tentang multikultural yang memadai. Kekurangpengetahuan ini bisa menjadi penghambat dalam upaya pelaksanaan pendidikan Islam berbasis multikultural. Untuk menumbuhkan pengetahuan tersebut, Unisma mengupayakannya melalui beberapa kegiatan, yaitu kegiatan nonkulikuler yang diberikan dalam kegiatan Orientasi Kehidupan Kampus Mahasiswa Baru (Oshika Maba) dan Halaqoh Diniyah, serta kegiatan kurikuler melalui mata kuliah agama Islam. Karena sifatnya yang hanya pada pemberian pengetahuan, maka dalam kegiatan-kegiatan tersebut, mahasiswa hanya diberikan pengetahuan tentang multikultural dalam bentuk pemaparan materi, ceramah, dan kegiatan pembelajaran dalam kelas.

Dalam Oshika Maba, beberapa materi yang sarat dengan pengetahuan multikultural diantaranya: wawasan nusantara, pengenalan kampus, serta organisasi dan kegiatan kemahasiswaan. Setidaknya dalam tiga materi tersebut, terdapat beberapa penekanan nilai pendidikan multikultural, seperti nilai toleransi, demokrasi, keadilan dan kesetaraan.

Kemudian dalam Halaqoh Diniyah, terdapat beberapa materi yang bisa dikatakan sebagai pengetahuan tentang multikultural, yaitu: penanaman nilai Islam Ahlussunnah wal-Jama'ah dalam kehidupan sehari-hari, etika berpakaian dalam Islam, etika pergaulan dalam Islam, dan etika belajar dalam Islam. Jika materi-materi tersebut dihubungkan dengan prinsip-prinsip pengembangan pendidikan Islam berbasis multikultural yang ada di Unisma, maka materi-materi dalam Halaqoh Diniyah ini adalah bentuk implementasi dari prinsip keempat, yaitu Islam rahmatan lil'alamin sebagai leader.

Setelah mahasiswa mengikuti dua kegiatan tersebut, yang dilaksanakan selama satu minggu. Tidak lantas mahasiswa Unisma tidak diberikan lagi pengetahuan-pengetahuan tentang multikultural, karena proses multicultural knowing ini dilanjutkan dalam kegiatan kurikuler, yaitu melalui mata kuliah agama Islam 1-5 yang diberikan selama lima semester dan wajib diikuti oleh semua mahasiswa Unisma, tidak terkecuali mahasiswa non-Islam.

Dalam kurikulum mata kuliah Agama Islam, nampak beberapa materi yang saratdengan muatan multikultural, diantaranya: hakekat agama, kedudukan manusia, konsepsi tentang ketuhanan, akhlak terhadap sesama, akhlak terhadap negara, prinsip-prinsip aswaja, dan sikap perbedaan pendapat di kalangan Sahabat Nabi Saw.

Materi tersebut diberikan berkala dari mata kuliah Agama Islam satu sampai Agama Islam lima. Dengan demikian, hampir setiap 
ISTIGHNA, Vol. 2, No 2, Juli 2019 P-ISSN 1979-2824 E-ISSN 2655-8459

Homepage: http://e-journal.stit-islamic-village.ac.id/index.php/istighna

Ahmad Muzakkil Anam

Penanaman Nilai-Nilai Pendidikan Islam Multikultural Di Perguruan Tinggi

Keagamaan Islam (Studi Kasus Di Universitas Islam Malang)

semesternya, mahasiswa Unisma diberikan pengetahuan-pengetahuan seputar multikultural, baik itu terkait dengan perbedaan-perbedaan atau dalam hal berinteraksi dengan sesama.

b. Multicultural Feeling

Jika dalam multicultural knowing mahasiswa diberikan pengetahuan terkait dengan multikultural, maka dalam hal multicultural feeling ini, Unisma lebih menekankan pada internalisasi nilai-nilai atau pengetahuan akan multikultural dalam kehidupan sehari. Karenanya, dalam prosesnya pun juga berbeda. Jika pada kegiatan multicultural knowing, mahasiswa cenderung pasif, yakni hanya menerima materimateri tentang multikultural, maka dalam proses multicultural feeling ini mahasiswa lebih aktif dalam menerapkan apa yang mereka telah ketahui tentang bagaimana seharusnya bersikap kepada sesama teman, dosen atau sebagainya yang bisa jadi memiliki latar belakang berbeda satu sama lain. Karenanya, penekanan dalam multicultural feeling ini adalah lebih kepada mengembangkan apa yang telah diketahui.

Untuk menumbuhkan muticultiral feeling dalam diri mahasiswa, Unisma mengadakan kegiatan Student Day yang dilaksanakan selama sembilan minggu di semester pertama.Setiap minggunya kegiatan ini berlangsung di tiga tempat, yaitu masjid, lapangan olah raga dan ruang kelas/seminar. Jadi, di awal mahasiswa-mahasiswa semester pertama ini dikelompokkan ke dalam tiga kelompok besar. Kemudian setiap hari Rabu, masing-masing kelompok menempatkan diri di tempat yang telah ditentukan. Untuk yang di masjid, pengembangannya lebih kepada aspek kerohanian, kemudian yang di lapangan olah raga adalah dalam hal pengembangan minat dan bakat, sementara yang di ruang kelas/seminar lebih ditekankan dalam pengembangan keilmiahan.

Karena lebih bersifat pengembangan atas pemahaman multikultural, maka dalam segi materi memang tidak begitu nampak muatan-muatan multikultural. Tetapi memang lebih kepada bagaimana agar mahasiswa dapat berinteraksi dan bekerjasama satu sama lain dalam kegiatan Student Day. Di samping itu, juga ditekankan dalam kegiatan Student Day ini untuk dikembangkan beberapa nilai pendidikan multikultural, tabel berikut akan memberikan gambaran umum tentang nilai-nilai Pendidikan multikultural dalam Student Day:

Tabel. 2. Nilai-nilai Pendidikan multikultural dalam Student Day

\begin{tabular}{|c|c|c|}
\hline No & $\begin{array}{c}\text { Nilai Pendidikan } \\
\text { Multikultural }\end{array}$ & Deskripsi \\
\hline 1 & Nilai Toleransi & $\begin{array}{l}\text { - Dalam semua kegiatan, nilai toleransi } \\
\text { disampaikan di dalamnya. Toleransi dalam } \\
\text { arti sikap menghargai, menghormati, atau } \\
\text { membolehkan pendirian (pendangan, } \\
\text { pendapat, kepercayaan, kebiasaan atau } \\
\text { kelakuan) orang lain. }\end{array}$ \\
\hline
\end{tabular}


ISTIGHNA, Vol. 2, No 2, Juli 2019 P-ISSN 1979-2824 E-ISSN 2655-8459

Homepage: http://e-journal.stit-islamic-village.ac.id/index.php/istighna

Ahmad Muzakkil Anam

Penanaman Nilai-Nilai Pendidikan Islam Multikultural Di Perguruan Tinggi

Keagamaan Islam (Studi Kasus Di Universitas Islam Malang)

\begin{tabular}{|c|c|c|}
\hline 2 & Nilai Demokrasi & $\begin{array}{l}\text { - Dalam hal minat dan bakat, mahasiswa diberi } \\
\text { kebebasan untuk mengembangkan apa yang } \\
\text { diinginkan. }\end{array}$ \\
\hline 3 & Nilai Kesetaraan & $\begin{array}{l}\text { - Semua mahasiswa wajib mengikuti kegiatan } \\
\text { Student Day, tanpa terkecuali }\end{array}$ \\
\hline 4 & Nilai Keadilan & $\begin{array}{l}\text { - Adil dimaksud adalah adil dalam arti } \\
\text { "membagi sama banyak", juga adil dalam arti } \\
\text { sesuai porsi. Adil yang pertama nampak } \\
\text { dalam kemampuan membaca Al-Qur'an. } \\
\text { Semua mahasiswa mempunyai kewajiban } \\
\text { untuk mampu membaca Al-Qur'an. Bagi } \\
\text { yang lulus, tidak perlu mengikuti pembinaan, } \\
\text { bagi yang tidak lulus diharuskan mengikuti } \\
\text { pembinaan. Kemudian adil yang kedua } \\
\text { adalah melanjutkan tentang } \\
\text { kemampuannbaca Al-Quran. Bahwasanya } \\
\text { kewajiban tersebut tidak dibebankan kepada } \\
\text { mahasiswa non-Islam. }\end{array}$ \\
\hline
\end{tabular}

Tabel di atas memberikan gambaran yang jelas tentang aspek apa saja yang hendak dikembangkan dalam keterkaitannya Student Day dengan nilai-nilai pendidikan multikultural secara umum, dan - sekali lagi - tidak nampak adanya pemberian materi secara khusus seperti pada proses multicultural knowing, melainkan lebih kepada agar bagaimana mahasiswa memiliki hak dan kewajiban yang sama serta didorong untuk apat saling menghormati dan menghargai atas perbedaan yang dimiliki oleh masing-masing kelompok baik dalam lingkup daerahn asal atau pun agama yang dipeluk.

Dari beberapa kegiatan multiultural knowing dan multicultural feeling tersebut. Mahasiswa Unisma pada akhirnya diharapkan memiliki kesadaran multikultural, yangmana dengannya para mahasiswa yang memiliki latar belakang perbedaan tersebut pada akhirnya bisa dapat hidup bersama dalam keharmonisan (living in harmony). Yaitu dapat saling menghormati, menghargai dan menerima segala bentuk perbedaan ada dengan tetap membiarkan setiap perbedaan tersebut mempertahankan keunikan serta kecirikhasannya masing-masing.

\section{Implikasi Penanaman Nilai-nilai Pendidikan Multikultural Terhadap Sikap Toleransi Mahasiswa Universitas Islam Malang}

Dari beberapa pernyataan mahasiswa Unisma yang memiliki latar belakang yang berbeda baik dari segi agama, maupun asal daerah samasama memiliki penilaian awal yang relatif sama satu sama lain terkait dengan "perbedaan" dan penyikapan terhadap "perbedaan" tersebut. Yaitu mereka sama-sama memiliki cara pandang yang bisa dikatakan negatif dan penuh kecurigaan kepada orang lain atau kelompok yang berbeda. Entah itu terkait agama orang lain, atau budaya orang lain. Cara pandang yang negatif 
ISTIGHNA, Vol. 2, No 2, Juli 2019 P-ISSN 1979-2824 E-ISSN 2655-8459

Homepage: http://e-journal.stit-islamic-village.ac.id/index.php/istighna

Ahmad Muzakkil Anam

Penanaman Nilai-Nilai Pendidikan Islam Multikultural Di Perguruan Tinggi

Keagamaan Islam (Studi Kasus Di Universitas Islam Malang)

ini berimplikasi pada keengganan mahahsiswa untuk dapat berbaur satu sama lain.

Namun, cara pandang yang negatif tersebut berangsur-angsur mulai berubah ke arah yang lebih positif. Terlebih di saat mereka kemudian dipertemukan dalam beberapa kegiatan yang ada di Unisma yang mau tidak mau mempertemukan mereka dengan berbagai mahasiswa dengan latar belakang yang berbeda. Sikap negatif dan penuh kecurigaan itu pun akhirnya berubah menjadi sikap yang lebih bisa menerima dan memahami.

\section{E. PEMBAHASAN}

1. Penanaman Nilai-nilai Pendidikan Multikultural di Universitas Islam Malang Malang

Dalam rangka menanamkan nilai-nilai pendidikan multikultural sebagaimana di sebut di atas, Unisma memiliki beberapa prinsip, yang antara lain: keterbukaan, toleransi, kesatuan dalam perbedaan, dan Islam rahmatan lil'alamin sebagai leader. Prinsip-prinsip jika dilihat dari prinsipprinsip pendidikan Islam multikultural, maka akan nampak beberapa kesamaan. Tabel berikut akan memberikan gambaran yang lebih jelas kaitannya dengan prinsip-prinsip penanaman nilai-nilai pendidikan multikultural ini.

\section{Gambar 2. Antara Prinsip Pendidikan Islam Multikultural dan Prinsip Penanaman Nilai-nilai Pendidikan Multikultural}

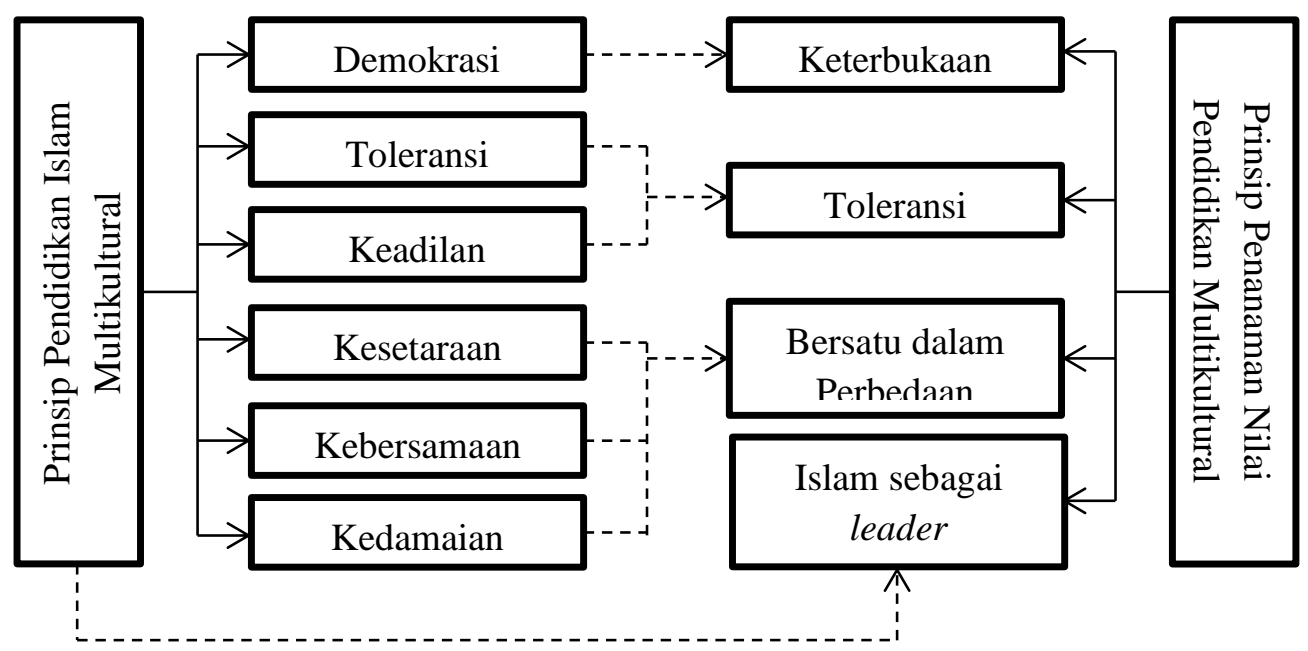

Dari gambar di atas diperoleh kesimpulan bahwa prinsip-prinsip penanaman nilai-nilai pendidikan multikultural yang ada di Unisma sejalan dengan prinsip-prinsip pendidikan Islam multikultural secara umum. ${ }^{10}$

Tidak hanya sejalan dengan prinsip pendidikan Islam multikultural, bahkan ketika dilihat dari sudut pandang tujuan pendidikan multikultural,

\footnotetext{
${ }^{10}$ Mahmud Arif, Pendidikan Islam Inklusif-Multikultural, (Yogyakarta: Jurnal Pendidikan Agama Islam, Vol. I, Nomor I, Juni 2012), hlm. 4-7
} 
ISTIGHNA, Vol. 2, No 2, Juli 2019 P-ISSN 1979-2824 E-ISSN 2655-8459

Homepage: http://e-journal.stit-islamic-village.ac.id/index.php/istighna

Ahmad Muzakkil Anam

Penanaman Nilai-Nilai Pendidikan Islam Multikultural Di Perguruan Tinggi

Keagamaan Islam (Studi Kasus Di Universitas Islam Malang)

prinsip-prinsip penanaman nilai-nilai pendidikan multikultural yang ada di Unisma juga memiliki ketersalingsamaan.

\section{Implementasi Penanaman Nilai-nilai Pendidikan Multikultural di Universitas Islam Malang Malang}

Dari paparan hasil penelitian nampak bahwa Unisma memiliki beberapa kegiatan yang sarat akan nilai-nilai pendidikan multikultural. Dimana kegiatan tersebut terpolakan menjadi dua, yaitu multicultural knowing dan multicultural feeling, yang dari keduan kegiatan tersebut mahasiswa terarahkan untuk sampai pada kondisi multicultural action.

Sementara itu, dalam teori pembentukan karakter Thomas Lickona, disebutkan adanya tiga komponen yang diperlukan kaitannya dengan pembentukan karakter seseorang. Ketiga komponen itu adalah adalah moral knowing yang terkait dengan aspek kognitif; moral feeling yang erat kaitannya dengan aspek afektif dan moral action yang merupakan wujud dari aspek psikomotorik. ${ }^{11}$

Ketersalinghubungan antar tiga komponen dalam teori pembentukan karakter tersebut juga berlaku dalam kegiatan penanaman nilai-nilai pendidikan multikultural yang ada di Unisma. Gambar berikut akan mengilustrasikan ketersalinghubungan antara komponen-komponen dalam penenaman nilai-nilai pendidikan multikultural di Unisma.

\section{Gambar 5.2. Implementasi Penanaman Nilai-nilai Pendidikan Multikultural} di Unisma

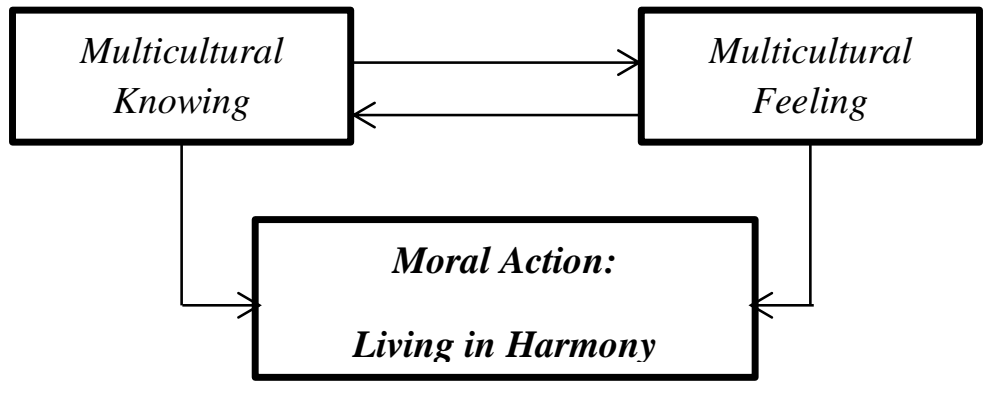

Gambar di atas memberikan gambaran bahwa ada tiga komponen yang itu saling terkait satu sama lain. Pertama adalah multicultural knowing, ini dimaknai sebagai penanaman pengetahuan tentang kemultikulturalan. Multicultural knowing ini diberikan Unisma kepada para mahasiswa melalu beberapa program dan kegiatan, diantaranya melalui Orientasi Kehidupan Kampus Mahasiswa Baru (Oshika Maba), Halaqoh Diniyah, dan Mata Kuliah Agama Islam 1-5.

Kedua adalah multicultural feeling, yaitu penanaman "rasa" multikultural dalam diri para mahasiswa atau dalam istilah lain dikenal sebagai aspek afektif. Untuk menumbuhkan multicultural feeling ini, di samping melalui kegiatan-kegiatan keseharian, Unisma juga memiliki

${ }^{11}$ Thomas Lickona, Educating for Character How..., hlm. 53-62 
ISTIGHNA, Vol. 2, No 2, Juli 2019 P-ISSN 1979-2824 E-ISSN 2655-8459

Homepage: http://e-journal.stit-islamic-village.ac.id/index.php/istighna

Ahmad Muzakkil Anam

Penanaman Nilai-Nilai Pendidikan Islam Multikultural Di Perguruan Tinggi

Keagamaan Islam (Studi Kasus Di Universitas Islam Malang)

kegiatan Student Day yang wajib diikuti oleh semua mahasiswa semester awal selama sembilan minggu. Melalui kegiatan ini, pengetahuan tentang multikultural para mahasiswa dikembangkan menjadi multicultural feeling. Sehingga, mereka tidak hanya tahu tentang multikultural, melainkan juga meyakini dengan sepenuhnya bahwa multikultural adalah realita yang ada di sekitar mereka yang harus mereka terima dengan sikap yang positif.

Ketiga, adalah dapat hidup bersama dalam suasasan yang harmonis (living in harmony). Dalam teori pembentukan karakter Thomas Lickona, komponen ini disebut sebagai moral action. Dimana moral action ini lebih dari hanya sekedar tahu (moral knowing) dan merasa (moral feeling), melainkan juga ada kemampuan, keinginan dan pada akhirnya membiasakan diri dalam melaksanakan apa yang diyakini sebagai sesuatu yang benar. Dalam hal ini, moral knowing bisa dikatakan sebagai puncak dari pendakian pembentukan karakter Thomas Lickona, yang jika ditarik ke dalam implementasi pendidikan islam berbasis multikultural yang ada di Unisma terwujud dalam bentuk living in harmony, yaitu dapat hidup bersama dalam kedamaian , kerukunan serta keharmonisan dengan tetap saling menghargai, menghormati dan menerima keberbedaan yang ada di sekitar dengan sikap yang positif.

\section{Implikasi Penanaman Nilai-nilai Pendidikan Multikultural Terhadap Sikap Toleransi Mahasiswa Universitas Islam Malang Malang}

Jika didasarkan pada teori pembentukan karakter Thomas Lickona, implikasi yang dimaksud dalam sub bab ini masuk pada komponen moral action. Dimana kepemilikan sikap toleransi ini dalam diri mahasiswa menjadi tujuan akhir dari penanaman nilai-nilai pendidikan multikulural itu sendiri.

Sikap itu sendiri secara umum memiliki tiga komponen dasar, seperti yang dinyatakan oleh Azwar S., bahwa ketiga komponen itu adalah kognitif, afektif dan konatif. ${ }^{12}$ Ketiganya secara substansi memiliki kesamaan dengan komponen teori pembentukan karakter Thomas Lickona dan juga dalam hal implementasi pendidikan Islam berbasis multikultural di Unisma. Ketersesuaian antara komponen sikap, komponen pembentukan karakter serta implementasi penanaman nilai-nilai pendidikan multikultural ini juga memiliki keterkaitan satu sama lain. Sikap toleransi hanya akan sampai pada taraf kognitif, jika dalam penanaman nilai-nilai pendidikan multikultural hanya berhenti pada proses multicultural knowing saja. Pun demikian sebaliknya, proses penanaman nilai-nilai pendidikan multikultural yang bisa menyentuh sampai pada taraf multicultural action akan menumbuhkan sikap toleransi yang sampai pada taraf konatif, yaitu sikap yang memiliki kecenderungan untuk melakukan, tidak hanya sekedar tahu.

Adapun dari paparan data yang telah dibahas dalam bab sebelumnya, nampak adanya perubahan sikap toleransi ke arah yang lebih positif. Artinya,

${ }^{12}$ Azwar S.,Azwar S., Sikap Manusia Teori dan Pengukurannya, cet. 2, (Yogyakarta: Pustaka Pelajar,2011), hlm. 13-15 
ISTIGHNA, Vol. 2, No 2, Juli 2019 P-ISSN 1979-2824 E-ISSN 2655-8459

Homepage: http://e-journal.stit-islamic-village.ac.id/index.php/istighna

Ahmad Muzakkil Anam

Penanaman Nilai-Nilai Pendidikan Islam Multikultural Di Perguruan Tinggi

Keagamaan Islam (Studi Kasus Di Universitas Islam Malang)

sikap ini memiliki kecenderungan tindakan ke arah mendekati, menyenangi, dan mengharapkan obyek tertentu, yang dalam hal ini adalah terkait dengan perbedaan latar belakang para mahasiswa yang pada awalnya memiliki penilaian negatif kepada orang lain yang berbeda telah berubah menjadi penilaian yang positif, yang awalnya saling mencurigai pada akhirnya dapat berteman dekat dengan baik.

\section{F. KESIMPULAN}

Penanaman nilai-nilai pendidikan multikultural yang ada di Unisma dikembangkan berdasarkan empat prinsip dasar yang saling terkait, yaitu: keterbukaan (openness), toleransi (tolerance), bersatu dalam perbedaan (unity in diversity), dan Islam rahmatan lil'alamin sebagai leader.

Adapun dalam implementasinya, Unisma menyelenggarakan beberapa kegiatan yang ditujukan dalam rangka mengimplementasikan pendidikan Islam berbasis multikultural tersebut terpolakan menjadi dua pola umum, yaitu kegiatan multicultural knowing dan multicultural feeling.

Dari dua kegiatan tersebut, memiliki tujuan akhir yaitu agar mahasiswa Unisma dapat hidup berdampingan dengan sesama mahasiswa yang memiliki latar belakang yang berbeda dengan tanpa menghilangkan ciri khas dari masingmasing kelompok. Dalam hal ini, sikap toleransi menjadi hal yang mutlak untuk dapat mewujudkan kehidupan yang harmoni (living in harmony) dalam komunitas yang multikultural.

\section{REFERENSI}

Arif, Mahmud. Pendidikan Islam Inklusif-Multikultural. Yogyakarta: Jurnal Pendidikan Agama Islam. Volume I. Nomor I. Juni. 2012.

Halili dan Bonar Tigor Naipospos. Stagnasi Kebebasan Beragama: Laporan Kondisi Kebebasan Beragama/Berkeyakinan di Indonesia Tahun 2013. Bendungan Hilir: Pustaka Masyarakat Setara. 2014.

Halili dan Bonar Tigor Naipospos. Dari Stagnasi Menjemput Harapan Baru: Kondisi Kebebasan Beragama/Berkeyakinan Di Indonesia Tahun 2014. Bendungan Hilir: Pustaka Masyarakat Setara. 2015.

Halili dan Bonar Tigor Naipospos. Laporan Kondisi Kebebasan Beragama/Berkeyakinan di Indonesia 2015; Politik Harapan Minim Pembuktian. Bendungan Hilir: Pustaka Masyarakat Setara. 2016

http://www.wahidinstitute.org/wi-id/, diakses tanggal 21 Januari 2016.

Lickona, Thomas. Educating for Character How Our School Can Teach Respect and Responsbility. New York: Bantam Bookss. 1992.

Maksum, Ali. Pluralisme dan Multikulturalisme; Paradigma Baru Pendidikan Islam di Indonesia. Malang: Aditya Media Publishing. 2011.

Peraturan Pemerintah Nomor 5 Tahun 2007 
ISTIGHNA, Vol. 2, No 2, Juli 2019 P-ISSN 1979-2824 E-ISSN 2655-8459

Homepage: http://e-journal.stit-islamic-village.ac.id/index.php/istighna

Ahmad Muzakkil Anam

Penanaman Nilai-Nilai Pendidikan Islam Multikultural Di Perguruan Tinggi

Keagamaan Islam (Studi Kasus Di Universitas Islam Malang)

Rossidy, Imron. Pendidikan Berparadigma Inklusif Upaya Memadukan Pengokohan Akidah dengan Pengembangan Sikap Toleransi dan Kerukunan. Malang: UIN Malang Press. 2009.

S., Azwar, Sikap Manusia Teori dan Pengukurannya. Cetakan ke-2. Yogyakarta: Pustaka Pelajar.2011.

Sulalah. Pendidikan Multikultural; Didaktika Nilai-nilai Universalitas Kebangsaan. Malang: UIN-Maliki Press. 2011.

Tim Penulis. Kewarganegaraan, Suku Bangsa, Agama, dan Bahasa Sehari-hari Penduduk Indonesia; Hasil Sensus Penduduk 2010. Jakarta: Badan Pusat Statistik. 2011.

Tim Penyusun. Laporan Tahunan Kebebasan Beragama/Berkeyakinan dan Intoleransi 2013. Jakarta: The Wahid Institute. 2013.

Yamin, Moh. dan Vivi Aulia. Meretas Pendidikan Toleransi; Pluralisme dan Multikulturalisme sebuah Keniscayaan Peradaban. Malang: Madani Media. 2011. 